\title{
Pengaruh Valsartan Terhadap Fibrosis Ginjal pada Obstruksi Ureter
}

\author{
Alvarino
}

\section{Abstrak}

Pendahuluan : Obstruksi ureter merupakan kondisi yang dapat terjadi pada setiap usia dengan level bervariasi dengan efek terburuk berupa gagal ginjal permanen. Terdapat berbagai mekanisme yang berperan dalam terjadinya kerusakan ginjal pada obstruksi ureter. Penelitian ini bertujuan untuk mengamati pengaruh valsartan untuk memperbaiki kerusakan ginjal pada kondisi tersebut. Metode : Dilakukan penelitian eksperimental menggunakan 30 ekor tikus wistar dengan obstruksi ureter unilateral melalui pengikatan ureter kiri yang dibagi menjadi dua kelompok, tanpa pemberian valsartan dan dengan pemberian valsartan. Pada hari ke-14 dinilai dan dibandingkan fibrosis interstisial, degenerasi hidrofik, dan atrofi tubulus pada kedua kelompok dengan pulasan hematoksilin-eosin. Hanya tikus yang tetap hidup hingga melewati hari ketujuh yang dimasukkan dalam penelitian. Hasil : Dari tiga belas tikus wistar pada kelompok obstruksi ureter unilateral tanpa pemberian valsartan, didapatkan 11 tikus mengalami fibrosis interstisial pada ringan dan 2 tikus mengalami fibrosis interstisial sedang, sementara seluruh tikus wistar pada kelompok dengan valsartan mengalami fibrosis interstisial ringan $(p>0.05)$. Tidak terdapat perbedaan bermakna untuk degenerasi hidrofik epitel tubulus antara kelompok tanpa valsartan dan dengan valsartan (31.46 vs 33.67, $\mathrm{p}>0.05)$. Tidak terdapat pula perbedaan bermakna untuk atrofi tubuli antara kedua kelompok (61.78 vs $62.07, \mathrm{p}>0.05)$. Kesimpulan : Pemberian valsartan dengan dosis antihipertensi tidak mengurangi tingkat fibrosis interstisial, degenerasi hidrofik, maupun atrofi tubulus pada obstruksi ureter unilateral pada tikus wistar

Kata kunci: obstruksi ureter unilateral, valsartan, fibrosis interstisial

\section{Abstract}

Introduction: Ureteral obstruction is a condition that might happen at any age in any level with the worst complication is permanent renal damage. There are several mechanisms that play role in renal damage in ureteral obstruction. This experimental research is aimed to observe the effect of valsartan to attenuate renal damage in unilateral ureteral obstruction. MethodsExperimental research was performed using 30 wistar rats with unilateral ureteral obstruction achieved by ligation of the left ureter. Rats then divided into two groups, no treatment group and valsartan group. At the 14th day, evaluation was performed to compare interstitial fibrosis, hydrophilic degeneration, and tubular atrophy between the two groups using haematoxylin-eosin staining. Only rats survive until at least 7th day are included in the study. ResultFrom thirteen wistar rats in no treatment group, two of them having moderate interstitial fibrosis and eleven with mild interstitial fibrosis while all rats in valsartan group had mild interstitial fibrosis $(p>0.05)$. There is no significant difference on hydrophilic degeneration between no treatment and valsartan group (31.46 vs 33.67, $p>0.05$ ). There is also no significant difference in tubular atrophy between the two groups (61.78 vs 62.07, $p>0.05)$. ConclusionValsartan therapy in antihypertensive dosage has no significant effect in to attenuate interstitial fibrosis, hydrophilic degeneration, and tubular atrophy in unilateral ureteral obstruction in wistar rats.

Keywords: unilateral ureteral obstruction, valsartan, interstitial fibrosis

Affiliasi penulis : Bagian IImu Bedah Sub Divisi Urologi FK Unand Korespondensi : Alvarino, Bagian IImu Bedah Sub Divisi Urologi FK Unand, alvarinouro@yahoo.com Telp: 0811936848

\section{Pendahuluan}

Obstruksi ureter merupakan suatu kondis yang dapat terjadi pada setiap usia dengan level dan efek yang bervariasi. Penyebabnya dapat berupa kelainan kongenital, didapat, maupun jinak atau ganas. Berat tidaknya efek yang ditimbulkan dipengaruhi oleh berbagai aspek antara lain derajat obstruksi, kronisitas, kondisi ginjal awal, potensi perbaikan ginjal, dan faktor lain seperti adanya infeksi, dengan efek terburuk dapat berupa gagal ginjal permanen.

Prevalensi obstruksi yang didapat dari sebuah seri autopsi yang melibatkan 59.064 subyek dari berbagai usia adalah 3.1\%. Hingga usia 20 tahun, prevalensi antara laki-laki dan perempuan adalah sama, kemudian terjadi lebih sering pada perempuan usia 20-60 tahun karena kehamilan dan keganasan ginekologis, dan lebih sering pada laki-laki usia di atas 60 tahun karena keganasan prostat. ${ }^{1}$

Perlu dijelaskan bahwa terdapat perbedaan antara hidronefrosis dengan nefropati obstruktif. Hidronefrosis merupakan keadaan di mana terjadi dilatasi pada pelvis atau kaliks ginjal yang dapat terjadi dengan maupun tanpa obstruksi. Sementara nefropati obstruktif kerusakan anatomi atau fungsional dari ginjal akibat adanya obstruksi. ${ }^{1}$ Pada dewasa, seringnya nefropati obstruktif disebabkan oleh batu, ${ }^{2}$ sementara pada anak-anak umumnya kongenital dengan penyebab tersering stenosis pada ureteropelvic junction. ${ }^{3}$

Obstruksi dapat menyebabkan terjadinya perubahan struktur ginjal termasuk di dalamnya fibrosis interstisial, atrofi dan apoptosis tubulus, dan inflamasi. ${ }^{1}$ Berbagai faktor diperkirakan berperan dalam terjadinya proses tersebut antara lain stress oksidatif dan inflamasi. ${ }^{4,5}$ Banyak hal yang berperan 
dalam proses ini, namun yang paling mendominasi adalah transforming growth factor beta (TGF-ß), angiotensin II, nuclear factor $\mathrm{KB}$ (NFKB), dan TNF- $\alpha$ yang diproduksi oleh sel tubulus dan interstisial ginjal sendiri maupun dari makrofag. ${ }^{1}$

Pada keadaan obstruksi, infiltrasi makrofag menstimulasi sintesis TGF-B yang diproduksi oleh epitel tubulus ginjal dan fibroblast interstisial. ${ }^{1,3}$ Melalui kedua reseptornya yaitu TGF-B1 dan TGF-B2 yang fungsinya saling menguatkan, kondisi ini mengakibatkan penumpukan kolagen dengan hasil akhir fibrosis interstisial, apoptosis sel epitel, dan atrofi tubulus. Sementara dalam keadaan obstruksi ureter unilateral, reseptor TGF-ß1 akan meningkat jumlahnya sehingga efek yang terjadi akan berlipat ganda. ${ }^{3}$

Sistem renin-angiotensin-aldosteron juga berperan dalam keadaan ini. Sistem renin-angiotensinaldosteron meningkatkan ekspresi TNF- $\alpha$ dan NFkB, sementara angiotensin II berperan meningkatkan ekspresi TGF-B1 pada kondisi obstruksi ureter unilateral. ${ }^{1}$ Efek angiotensin II bekerja melalui kedua reseptornya yaitu AT1 dan AT2, walaupun pada mamalia dewasa, AT1 memiliki peranan yang lebih kuat.

Ekspresi NFKB yang makin meningkat menyebabkan terjadinya proses fibrosis sedangkan NFKB sendiri memiliki efek umpan balik positif terhadap produksi angiotensin II sehingga efek yang dihasilkan lebih berat. Sementara TNF-a merupakan sitokin yang dapat secara langsung menyebabkan apoptosis pada inflamasi ginjal. ${ }^{1,3,5}$

Kelompok obat yang dapat mempengaruhi aksis renin-angiotensin-aldosteron adalah dari golongan angiotensin-converting enzyme inhibitor (ACE-i) dan angiotensin II receptor blocker yang keduanya digunakan sebagai terapi hipertensi. Pemberian ACE-I atau angiotensin II receptor blocker dapat mengurangi ekspresi TGF- $B$, menurunkan produksi matriks ekstraseluler, aktivasi $\mathrm{NF}_{\mathrm{KB}}$, dan proliferasi fibroblas yang berujung pada fibrosis. Namun, ACE-I hanya dapat mengurangi produksi angiotensin II yang dipengaruhi oleh angiotensinconverting enzyme, sementara angiotensin II receptor blocker memiliki efek pada semua level yang memproduksi angiotensin II. [6] Selain itu angiotensin II receptor blocker tidak memiliki efek ACE-I yang tidak menguntungkan seperti batuk dan angioedema. ${ }^{\text {}}$

Valsartan merupakan derivat tetrazol nonpeptida yang poten yang dapat menurunkan tekanan darah sehingga digunakan sebagai terapi antihipertensi. Valsartan bekerja dengan cara inhibisi selektif pada reseptor angiotensin II tipe I (AT1). Afinitasnya terhadap AT1 20.000 kali lebih besar dibandingkan terhadap AT2. Valsartan tersedia dalam dosis 10, 20, 4080,160 , dan $320 \mathrm{mg}$ di mana semua dosis dianggap aman dan dapat ditoleransi. ${ }^{8}$ Efek antihipertensi valsartan mulai terilihat pada penggunaan dosis $80 \mathrm{mg}$, dengan ambang batas dosis yang dapat menurunkan tekanan darah adalah 1 $\mathrm{mg} / \mathrm{kgBB}$. $^{-10}$ Dibandingkan dengan kelompok angiotensin receptor blocker lainnya, valsartan dianggap memiliki efek antihipertensi yang lebih cepat, lebih besar, dan lebih baik dengan efek samping yang juga lebih ringan. ${ }^{9}$

Penelitian ini bertujuan untuk mengamati efek pemberian valsartan dalam perbaikan kerusakan ginjal pada obstruksi ureter unilateral berupa fibrosis dengan cara membandingkannya dengan kelompok hewan coba yang tidak diberikan terapi apapun. Hewan coba yang digunakan pada penelitian ini adalah tikus wistar.

\section{Metode Penelitian \\ Jenis Penelitian}

Penelitian ini merupakan penelitian eksperimental untuk mengetahui efek valsartan terhadap kerusakan ginjal pada obstruksi ureter unilateral dengan menggunakan hewan coba berupa tikus wistar.

\section{Waktu dan Tempat Penelitian}

Penelitian dilakukan selama dua minggu di laboratorium hewan coba Jurusan Farmasi Fakultas Matematika dan IImu Pengetahuan Alam Universitas Andalas dan dua minggu di laboratorium Patologi Anatomi Fakultas Kedokteran Universitas Andalas.

\section{Desain Penelitian}

Penelitian ini menggunakan tikus wistar yang dibagi menjadi dua kelompok. Kelompok pertama (A) adalah kelompok kontrol di mana tikus wistar hanya mendapat perlakuan berupa pengikatan ureter kiri tanpa diberikan terapi apapun. Kelompok kedua (B) adalah kelompok perlakuan di mana tikus wistar yang telah diikat ureter kirinya mendapatkan terapi valsartan. Semua hewan coba pada kedua kelompok dimatikan pada hari ke-14 untuk diambil ginjalnya kemudian dilakukan pemeriksaan patologi anatomi untuk melihat fibrosis ginjal, degenerasi hidrofik, dan atrofi tubuli. Bila terdapat hewan coba yang mati sebelum hari ke-7, hewan coba tersebut tidak dimasukkan ke dalam perhitungan akhir. Hewan coba yang mati setelah hari ke-7 selama masa penelitian tetap disertakan dalam perhitungan akhir.

\section{Besar Sampel Penelitian}

Dengan menggunakan tingkat kemaknaan hingga 1.96, didapatkan besar sampel untuk penelitian adalah delapan ekor tikus wistar per kelompok. Jumlah ini dinaikkan menjadi 15 ekor tikus wistar per kelompok.

\section{Prosedur Penelitian}

Hewan coba berupa tikus wistar jantan berusia tiga bulan dengan berat antara 150-200 gram yang sehat dan tidak memiliki cacat anatomi. Tikus wistar kemudian diadaptasi selama satu minggu, diberi pakan standar dan minum. Tiga puluh ekor tikus wistar dibagi menjadi dua kelompok perlakuan di mana masing-masing kelompok terdiri dari 15 ekor tikus. Kelompok pertama $(A)$ adalah kelompok kontrol di mana tikus wistar hanya mendapat perlakuan berupa pengikatan ureter kiri tanpa diberikan terapi apapun. Kelompok kedua (B) adalah kelompok perlakuan di mana tikus wistar yang telah diikat ureter kirinya mendapatkan terapi valsartan.

Kemudian dilakukan laparotomi pada hewan coba dengan pembiusan menggunakan dietil eter. Dilakukan sayatan perut pada garis tengah dan kemudan ureter kiri diidentifikasi. Ureter kemudian diikat menggunakan prolene 4.0 pada bagian proksimal. Perut ditutup dengan jahitan silk 3.0 dan kemudian dibubuhi betadine. Hewan coba tidak mendapatkan obat atau zat tambahan lain selain pakan standar, minum, dan valsartan hanya pada kelompok perlakuan. Dosis valsartan yang diberikan pada hewan coba kelompok B adalah $1.44 \mathrm{mg} / 200$ $\mathrm{mg} /$ hari yang merupakan dosis yang telah dikonversi 
menggunakan tabel konversi dosis berdasarkan dosis $80 \mathrm{mg} /$ hari pada manusia dengan berat badan $70 \mathrm{~kg}$. Perawatan luka operasi pada hewan coba menggunakan betadine yang diberikan pada luka operasi dua kali per hari. Hingga akhir masa penelitian, tidak ada hewan coba yang mati dengan infeksi pada luka operasi.

Pada hari keempat belas, hewan coba dimatikan dengan dietil eter dan dilakukan laparotomi. Ginjal kiri diambil dan dibawa dalam botol berisi formalin. Ginjal diproses dengan metode baku histologi menggunakan pewarnaan hematoksilineosin, lalu dilakukan pemeriksaan histologi. Data ditulis dalam bentuk formulir.

Untuk fibrosis interstisial dihitung per 100 tubuli dan dikelompokkan menjadi ringan $(<25 \%$ per 100 tubuli), sedang (26-50\% per 100 tubuli), dan berat (> 50\% per 100 tubuli) berdasarkan Guideline for scoring and reporting interstitial fibrosis. [11] Untuk data degenerasi hidrofik dihitung per 100 epitel tubuli, sementara untuk data atrofi tubuli dihitung per 100 tubuli. Kedua data tersebut disajikan dalam bentuk data numerik.

\section{Variabel Penelitian}

Variabel independen pada penelitian ini adalah fibrosis ginjal, degenerasi hidrofik, dan atrofi tubuli. Sementara variabel dependen adalah perlakuan terhadap tikus wistar berupa pemberian valsartan dan tidak diberikan valsartan.

\section{Analisa Data}

Data disajikan sesuai penilaian pemeriksaan patologi anatomi untuk masing-masing variabel independen. Untuk data kategorik, perbandingan dilakukan menggunakan Fisher's Exact Test, sementara untuk data numerik, perbandingan rerata kedua kelompok diuji menggunakan uji Mann Whitney U. Seluruh pengujian dilakukan satu arah (one tail). Seluruh analisa data dilakukan menggunakan program SPSS 16.0.

\section{Hasil Penelitian}

Sebanyak tiga puluh ekor tikus wistar dibagi rata ke dalam dua kelompok yaitu kelompok kontrol (A) di mana ureter kiri tikus diikat tanpa diberikan apapun dan kelompok perlakuan (B) di mana ureter kiri tikus diikat dan diberikan valsartan. Pada hari ke14, tikus dimatikan untuk diambil ginjalnya. Dari kelompok $\mathrm{A}$, terdapat dua buah tikus yang tidak dimasukkan ke dalam perhitungan akhir karena tikus mati sebelum hari ketujuh. Penyebab kematian pada salah satu tikus adalah pembiusan yang terlalu dalam dengan dietil eter sementara pada tikus yang lain tidak diketahui. Semua tikus pada kelompok B diikutkan pada perhitunganan akhir karena tidak ada tikus yang mati sebelum hari ketujuh penelitian.

Dari tiga belas tikus wistar pada kelompok $A$ yang tidak diberikan valsartan, sebelas tikus mengalami fibrosis interstisial ringan dengan tingkat fibrosis interstisial paling rendah adalah 0 per 100 tubuli dan paling tinggi $15 \%$ per 100 tubuli. Sementara terdapat dua ekor dengan tingkat fibrosis sedang yaiut $30 \%$. Walaupun terdapat dua ekor tikus wistar pada kelompok ini dengan hasil tingkat fibrosis 0 per 100 tubuli, bukan berarti kedua ekor tikus ini normal karena tetap terdapat gambaran fibrosis interstisial dan degenerasi hidrofik pada tikus. Pada kelompok $B$, seluruh tikus mengalami fibrosis interstisial dengan tingkat fibrosis ringan. Pada kelompok ini, fibrosis interstisial yang paling rendah adalah $8 \%$ per 100 tubuli dan tertinggi adalah $17 \%$ per 100 tubuli.

Untuk degenerasi hidrofik, seluruh hewan coba pada kelompok A mengalami degenerasi hidrofik epitel tubuli dengan nilai tertinggi 60 per 100 epitel tubuli dan terendah 20 per 100 epitel tubuli. Pada kelompok $\mathrm{B}$, nilai tertinggi menjadi 30 per 100 epitel tubuli dan terendah 60 per 100 epitel tubuli.

Atrofi tubuli juga dinilai pada penelitian ini. Untuk hewan coba pada kelompok $A$, nilai tertinggi adalah 76 per 100 tubuli sementara nilai terendah adalah 33 per 100 tubuli. Pada kelompok B, nilai tertinggi adalah 75 per 100 tubuli dan terendah adalah 40 per 100 tubuli.. Keseluruhan data tersebut disajikan pada tabel berikut.

Table 1: Hasil Penelitian

\begin{tabular}{ccccccc}
\hline $\begin{array}{c}\text { Tikus } \\
\text { Wistar }\end{array}$ & $\begin{array}{c}\text { Fibrosis Interstisial } \\
\text { per 100 tubuli }\end{array}$ & $\begin{array}{c}\text { Degenerasi } \\
\text { hidrofik epitel } \\
\text { tubuli per 100 } \\
\text { epitel tubuli }\end{array}$ & $\begin{array}{c}\text { Atrofi tubuli } \\
\text { per 100 } \\
\text { tubuli }\end{array}$ \\
\hline 1 & A & B & A & B & A & B \\
2 & Ringan & ringan & 26 & 33 & 70 & 75 \\
3 & Sedang & ringan & 20 & 30 & 60 & 72 \\
4 & Ringan & ringan & 35 & 35 & 70 & 68 \\
5 & Ringan & ringan & 30 & 35 & 65 & 65 \\
6 & Ringan & ringan & 50 & 35 & 40 & 40 \\
7 & Ringan & ringan & 20 & 33 & 75 & 74 \\
8 & Sedang & ringan & 60 & 33 & 33 & 75 \\
9 & Ringan & ringan & 30 & 35 & 64 & 69 \\
10 & Ringan & ringan & 35 & 30 & 60 & 72 \\
11 & Ringan & ringan & 20 & 35 & 76 & 45 \\
12 & Ringan & ringan & 30 & 33 & 60 & 72 \\
13 & Ringan & ringan & 25 & 35 & 60 & 40 \\
14 & Ringan & ringan & 28 & 35 & 70 & 45 \\
15 & - & ringan & - & 33 & - & 74 \\
& & ringan & - & 35 & - & 45 \\
\hline
\end{tabular}

setelah diolah dari data di atas, tidak terdapat perbedaan bermakna untuk fibrosis interstisial per 100 tubuli antara kelompok yang tidak diberi valsartan dengan kelompok yang diberi valsartan $(p=0.206$, Fisher's Exact Test).

Kedua kelompok juga tidak menunjukkan perbedaan bermakna pada degenerasi hidrofik epitel tubuli per 100 tubuli. Namun kelompok yang diberikan valsartan memang menunjukkan rerata yang lebih tinggi dibandingkan kelompok tanpa pemberian valsartan (33.67 vs 31.46, $p=0.052$ ). Untuk atrofi tubuli per 100 tubuli, kelompok yang tidak diberikan valsartan bahkan menunjukkan rerata yang sedikit lebih baik dibandingkan kelompok dengan pemberian valsartan, namun hal ini tidak berbeda bermakna (61.78 vs $62.07, p=0.555$ ).

\section{Diskusi}

Valsartan merupakan angiotensin II receptor blocker. Penggunaannya dalam penelitian diharapkan dapat mengurangi terjadinya kerusakan pada ginjal akibat obstruksi ureter unilateral. Hasil ini diharapkan dapat tercapai melalui mekanisme kerja valsartan yang akan menginhibisi selektif AT1 yang berperan dalam meningkatkan ekspresi TGF-ß1. Dengan demikian, fibrosis yang terjadi pada ginjal hewan coba yang diterapi dengan valsartan diharapkan lebih ringan dibandingkan yang tidak diberikan valsartan.

Hasil dari penelitian ini menunjukkan bahwa ginjal hewan coba yang tidak diberikan terapi valsartan memiliki tingkat fibrosis yang lebih tinggi dibandingkan 
dengan kelompok yang diberikan valsartan, namun perbedaannya tidak bermakna. Ini dapat dipahami karena sistem renin-angiotensin-aldosteron bukan merupakan satu-satunya mekanisme yang berperan dalam terjadinya fibrosis pada obstruksi ureter. $^{1-5}$ Terdapat banyak faktor lain yang digambarkan dalam skema di bawah ini.

Dari gambar tersebut, dapat dijelaskan bahwa peran valsartan sebagai ARB hanya berperan pada satu sisi untuk mencegah kerusakan ginjal pada obstruksi ureter. Selain itu, valsartan merupakan inhibitor selektif hanya pada AT1R saja, sementara angiotensin II mengaktivasi NFKB melalui AT1R dan AT2R. ${ }^{5}$ Penelitian menunjukkan pada tikus dengan AT1R yang sudah dilumpuhkan menunjukkan adanya infiltrasi monosit pada jaringan interstisial dan adanya aktivasi NFKB, di mana kedua proses ini dapat dihambat dengan menghambat AT2R. ${ }^{12}$ Dengan demikian, inhibisi selektif hanya pada AT1R seperti yang dilakukan oleh valsartan tidak cukup bermakna untuk menunjukkan perbaikan ginjal pada obstruksi ureter. Kombinasi inhibisi kedua reseptor angiotensin II mungkin dapat menunjukkan perbaikan yang lebih bermakna.

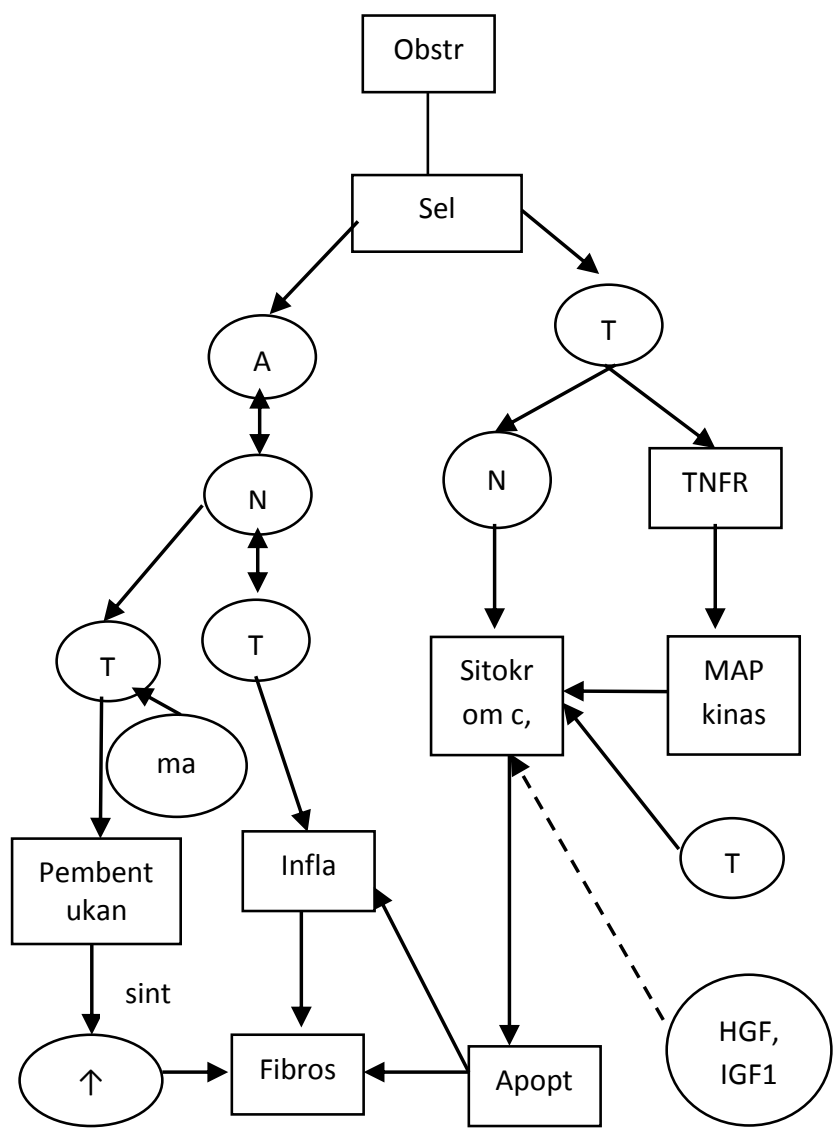

Gambar 1. Skema Terjadinya Fibrosis Interstisial dan Apoptosis pada Obstruksi Ureter

Ang II, angiotensin II; HGF, human growth factor; HSPs, heat shock proteins; IGF, insulin-like growth factor, JAK/STAT, Janus kinase/signal transducers and activators of transcription; MAP, mitogen-activated protein; NF-KB, nuclear factor $\kappa B$; TGF, transforming growth factor; TNF, tumor necrosis factor; TNFR1, tumor necrosis factor receptor 1. (Gambar diolah dari Campbell-Walsh Urology $10^{\text {th }}$ edition)
Stress oksidatif juga memiliki peranan dalam menyebabkan kerusakan ginjal pada obstruksi ureter. ${ }^{1,2,5}$ Pemberian valsartan tidak dapat menghambat fibrosis yang terjadi akibat stress oksidatif. Pemberian terapi antioksidan dikombinasikan dengan valsartan dapat diperhitungkan sebagai terapi preventif untuk mencegah kerusakan ginjal. Penelitian yang dilakukan oleh Lubis dan Alvarino dengan mengkombinasikan valsartan dan kurkumin menunjukkan perbedaan yang bermakna untuk tingkat fibrosis tubulus ginjal pada obstruksi ureter dibandingkan dengan kelompok yang hanya mendapat valsartan saja. ${ }^{13}$ Karena hal tersebut pula, degenrasi hidrofik maupun atrofi tubuli pada kedua kelompok percobaan juga tidak meberikan perbedaan yang bermakna.

Hasil dari penelitian ini berbeda dengan penelitian-penelitian sebelumnya yang menunjukkan adanya efek proteksi untuk

nefropati obstruktif yang diberikan oleh golongan ARB. ${ }^{14-18}$ Losartan misalnya, pemberiannya pada hewan coba dengan obstruksi ureter unilateral menunjukkan efek pencegahan terhadap terjadinya obstruksi ureter unilateral dan pencegahan terjadinya nefropati obstruktif pada pasien dengan diabetes mellitus tipe II. Sementara pemberian irbesartan dianggap efektif untuk melindungi terjadinya nefropati obstruktif pada penderita diabetes mellitus tipe II dan efek ini tidak bergantung pada efek antihipertensi yang ditimbulkannya.

Perlu diperhatikan bahwa dalam penelitian tersebut, losartan yang digunakan adalah dalam dosis $10 \mathrm{mg} / \mathrm{kgBB} /$ hari, sementara sebagai terapi antihipertensi, dosis losartan pada orang dewasa adalah $50 \mathrm{mg} /$ hari pada orang dewasa dengan berat badan $70 \mathrm{~kg} .{ }^{7,15}$ Terdapat perbedaan dosis yang besar antara dosis yang diberikan sebagai terapi antihipertensi dengan dosis yang bersifat renoprotektif.

Penelitian yang serupa dilakukan oleh Wu dkk, yang membandingkan kerusakan ginjal pada obstruksi ureter unilateral menggunakan valsartan saja dan kombinasi valsartan dengan aliskiren. ${ }^{19}$ Pada penelitian tersebut, terdapat perbedaan bermakna untuk tingkat fibrosis antara yang diterapi valsartan saja dengan yang diterapi kombinasi valsartan dan aliskiren. Wu dkk juga menjelaskan terdapat perbedaan bermakna untuk tingkat fibrosis antara hewan coba tanpa diberikan terapi apapun dengan hewan coba yang diberikan terapi valsartan saja, dengan dosis valsartan yang digunakan adalah 30 $\mathrm{mg} / \mathrm{kg} /$ hari. Sementara untuk hewan coba yang diterapi dengan valsartan $15 \mathrm{mg} / \mathrm{kg} / \mathrm{hari}$ tidak menunjukkan perbedaan yang bermakna.

Perlu diperhatikan bahwa dosis valsartan yang diberikan untuk mendapatkan efek renoprotektif pada penelitian tersebut adalah $30 \mathrm{mg} / \mathrm{kg} / \mathrm{hari}$. Sementara pada penelitian yang kami lakukan, kami menggunakan dosis antihipertensi valsartan yaitu 80 $\mathrm{mg} / \mathrm{hari}$ yang kami konversi ke dosis sesuai jenis hewan coba menggunakan tabel konversi dosis. Dengan berat hewan coba yang sama yaitu sekitar 200 gram, maka berdasarkan penelitian Wu dkk, efek renoprotektif baru dapat ditunjukkan dengan pemberian valsartan sebanyak $6 \mathrm{mg} / \mathrm{hari}$, sementara kami hanya memberikan $1.44 \mathrm{mg} / \mathrm{hari}$.

Valsartan merupakan obat yang bekerja dengan cara dose dependent. ${ }^{8-10}$ Ambang batas dosis yang dapat memberikan efek antihipertensi adalah 1 
$\mathrm{mg} / \mathrm{kgBB}$ sementara untuk menurunkan sebanyak 30 $\mathrm{mmHg}$, dibutuhkan dosis sebesar $1.4 \mathrm{mg} / \mathrm{kgBB}$.

Dengan demikian dapat disimpulkan bahwa pemberian valsartan saja dengan dosis antihipertensi tidak memiliki efek renoprotektif yang bermakna pada obstruksi ureter. Ini dikarenakan terdapat faktor lain yang menyebakan fibrosis interstisial tubulus yang tidak dapat dihambat dengan pemberian valsartan. Kombinasi pemberian valsartan dengan antioksidan dapat meberikan efek renoprotektif yang lebih baik dibandingkan pemberian valsartan saja.

Penelitian ini hanya membatasi diri pada parameter histologi dengan pemeriksaan hematoksilin eosin. Penambahan parameter lain seperti ukuran dan berat ginjal, kadar kreatinin serum, dan pemeriksaan imunohistokimia, serta marker lainnya diharapkan dapat membuat penelitian ini lebih bermakna.

\section{Kesimpulan dan Saran}

Pemberian valsartan dengan dosis antihipertensi tidak mengurangi tingkat fibrosis interstisial, degenerasi hidrofik, maupun atrofi tubulus pada obstruksi ureter unilateral tikus wistar. Hal ini disebabkan valsartan sebagai angiotensin /I receptor blocker tidak dapat menghambat seluruh jalur yang dapat menyebabkan terjadinya fibrosis. Dosis valsartan yang dapat memberikan efek renoprotektif juga masih diperdebatkan. Kombinasi penggunaan valsartan dengan antioksidan misalnya dapat meberikan efek renoprotektif yang bermakna.

Penelitian lebih lanjut perlu dilakukan untuk memperjelas peranan valsartan dalam menghambat fibrosis interstisial pada obstruksi ureter. Analisa dosis yang tepat untuk menghasilkan efek renoprotektif juga perlu dicari. Dengan demikian diharapkan valsartan dapat menjadi salah satu alternatif terapi untuk mencegah kerusakan ginjal akibat obstruksi ureter.

\section{Daftar Pustaka}

1. I. Singh, J. Strandhoy and D. Assimos, "Patophysiology of Urinary Tract Obstruction," in Campbell-Walsh Urology, Philadelphia, Elsevier Saunders, 2012, pp. 1087-1121.

2. M. Zecher, C. Guichard, M. Velasquez, G. Figuerosa and R. Rodrigo, "Implications of oxidative stress in the pathophysiology," Urology Research, vol. 37, pp. 19-26, 2009.

3. R. Chevalier, "Molecular and cellular pathophysiology," Pediatric Nephrology, vol. 13, pp. 612-619, 1999

4. B. Pat, T. Tang, C. Kong, Diannewatters, D. Johnson and G. G, "Activation of ERK in renal fibrosis after unilateral ureteral obstruction: Modulation by antioxidants," Kidney International, vol. 67, pp. 931-943, 2005.

5. M. Grande, F. Pérez-Barriocanal and J. LópezNovoa, "Role of inflammation in tubulo-interstitial damage associated to obstructive nephropathy," Journal of Inflammation, vol. 7, pp. 1-14, 2010.

6. S. Klahr and J. Morissey, "Comparative effects of ACE inhibition and angiotensin II receptor blockade in the prevention of renal damage," Kidney International, vol. 62, pp. S23-S26, 2002.

7. M. Maillard, G. Würzner, J. Nussberger, C. Centeno, B. Burnier and H. Brunner, "Comparative angiotensin II receptor blockade in healthy volunteers: The importance of dosing," Clinical Pharmacology and Therapeutics, vol. 71, pp. 6876, 2002
8. N. Siddiqui, A. Husain, L. Chaudhry, M. Alam and M. B. O. Mitrra, "Pharmacological and Pharmaceutical Profile of Valsartan: A Review," Journal of Pharmaceutical Science, vol. 01, no. 04, pp. 12-19, 2011.

9. M. Saydam and S. Takka, "Bioavailability File: Valsartan," Journal of Pharmacological Science, vol. 32, pp. 185-196, 2007.

10. L. Criscione, M. de Gasparo, P. Biihlmayer, S. Whitebread, H. Ramjoue and J. Wood, "Pharmacological profile of valsartan: a potent, orally active, nonpeptide antagonist of the angiotensin II AT1-receptor subtype," British Journal of Pharmacology, vol. 110, pp. 761-771, 1993.

11. C. Banff, "Draft guideline for scoring and reporting interstisial fibrosis," Working group on fibrosis, 2009.

12. V. Esteban, O. Lorenzo, M. Rupérez, Y. Suzuki, S. Mezzano, J. Blanco, M. Kretzler, T. Sugaya, J. Egido and M. Ruiz-Ortega, "Angiotensin II, via AT1 and AT2 receptors and NF-kappaB pathway, regulates the inflammatory response in unilatera ureteral obstruction," Journal of American Society of Nephrology, vol. 15, pp. 1514-1529, 2004.

13. A. Lubis $M$, "Pengaruh pemberian valsartan dan kurkumin pada obstruksi ureter unilateral," Departemen Bedah Fakultas Kedokteran Universitas Andalas, Padang, 2012.

14. J. Hvistendahl, T. Pedersen, J. Djurhuus, E. Pedersen and J. Frøkiær, "Losartan attenuates renal vasoconstriction in response to acute unilateral ureteral occlusion in pigs," Urology Research, vol. 30, pp. 169-177, 2002.

15. W. Manucha, L. Oliveros, L. Carrizo, A. Seltzer and P. Valles, "Losartan modulation on NOS isoforms and COX-2 expression in early renal fibrogenesis in unilateral obstruction," Kidney International, Vols. 2091-2107, p. 65, 2004.

16. B. Liu, H. Xia, J. Wu, X. Zhang, D. Liu and Y. Gong, "Influence of irbesartan on expression of ILK and its relationship with epithelialmesenchymal transition in mice with unilateral ureteral obstruction," Acta Pharmacol Sin, vol. 11, no. 28, pp. 1810-1818, 2007.

17. B. Brenner, M. Cooper, D. Zeeuw, W. Keane and e. al., "Effects of losartan on renal and cardiovascular outcomes in patients with type 2 diabetes and nephropathy," The New England Journal of Medicine, vol. 345, pp. 861-9, 2001.

18. E. Lewis and collegues, "Renoprotective effect if the angiotensin-receptor antagonist irbesartan in patients with nephropathy due to type 2 diabetes," The New England Journal of Medicine, vol. 345, pp. 851-60, 2001.

19. W. Wu, C. Chang, Y. Chiu, C. Ku, M. Wen, K. Shu and $\mathrm{M}$. Wu, "A reduction of unilateral ureteral obstruction-induced renal fibrosis by a therapy combining valsartan with aliskiren," American Journal of Physyology Renal Physiology, vol. 299, pp. F929-F941, 2010. 